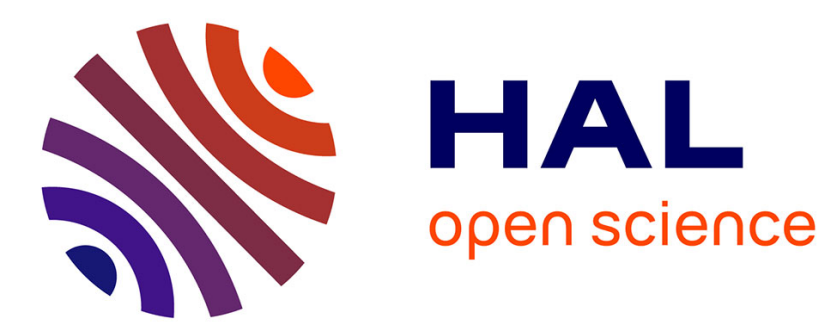

\title{
A new conception of the plastic and liquid limits of clay
}

\author{
A. Faure
}

\section{To cite this version:}

A. Faure. A new conception of the plastic and liquid limits of clay. Soil and Tillage Research, 1981, 1 (2), pp.97-105. hal-02718159

\section{HAL Id: hal-02718159 \\ https://hal.inrae.fr/hal-02718159}

Submitted on 1 Jun 2020

HAL is a multi-disciplinary open access archive for the deposit and dissemination of scientific research documents, whether they are published or not. The documents may come from teaching and research institutions in France or abroad, or from public or private research centers.
L'archive ouverte pluridisciplinaire HAL, est destinée au dépôt et à la diffusion de documents scientifiques de niveau recherche, publiés ou non, émanant des établissements d'enseignement et de recherche français ou étrangers, des laboratoires publics ou privés. 


\title{
A NEW CONCEPTION OF THE PLASTIC AND LIQUID LIMITS OF CLAY
}

\author{
A. FAURE \\ Station de Science du Sol, I.N.R.A. 84140 Montfavet (France)
}

(Accepted 18 August 1980)

\begin{abstract}
Faure, A., 1981. A new conception of the plastic and liquid limits of clay. Soil Tillage Res., 1: 97-105.

Soil compaction in the laboratory may show two particular points on the dry bulk density versus water content curve. At these points, dry bulk densities depend on the distribution and shapes and sizes of the soil particles and on the force or level of energy used in compaction. However, for a given force or energy level, water contents depend only on the kind of clay. It is shown that these two particular points correspond to Atterberg's plastic and liquid limits, each related to a specific level of energy. Thus the plastic index compares two characteristic water contents determined under identical experimental conditions.
\end{abstract}

\section{INTRODUCTION}

To ensure good crop growth the soil should have a sufficient bearing capacity to prevent excessive rutting and soil compaction by machinery which would be detrimental to crop development. Therefore, in view of increasing mechanisation, it is imperative to get to know as much as possible about soil behaviour at different water contents, caused either by weather effects or by human action.

The response of soil to compaction is a phenomenon of high complexity. It does not only depend on the nature and the distribution of sizes and shapes of the soil particles or on the water content at the time of compression, but it is also subject to the level and the mode of application of the energy used in compaction.

Therefore, when any comparison is made between field measurements and measurements in the laboratory, it must be done with great care as did McRae and Rutledge (1952).

The aim of this study was to obtain a better understanding of the part played by the clay fraction during the compression of a soil at different water contents. 


\section{MATERIALS AND METHODS}

Binary sand-clay mixtures were composed using fine Fontainebleau ( F) or coarse Brou (B) sand and kaolinite (K) or montmorillonite (M) clay both made monoionical in $\mathrm{Ca}^{2+}$.

Two modes of application of energy were used:

(1) Impact energy according to a modified Proctor test described in ASTM D 698-64T and AASHO T 9957 as mentioned by Burmister (1964), which is carried out as follows. A $70 \mathrm{~mm}$ diameter and $78 \mathrm{~mm}$ high mold, three compacted layers and three compactive forces: $E_{0}\left(0.6 \mathrm{MJ} \cdot \mathrm{m}^{-3}\right)$ by means of a $1 \mathrm{~kg}$ hammer dropping 30 times from a height of $20 \mathrm{~cm}$ on each layer, $E_{1}$ $\left(0.15 \mathrm{MJ} \cdot \mathrm{m}^{-3}\right)$ by means of a $0.5 \mathrm{~kg}$ hammer dropping 15 times from a height of $20 \mathrm{~cm}$ on each layer, and $E_{2}\left(2.4 \mathrm{MJ} \mathrm{m}^{-3}\right)$ by means of a $2 \mathrm{~kg}$ hammer dropping 60 times from a height of $20 \mathrm{~cm}$ on each layer.

(2) A constant pressure in a drained oedometer (consolidometer) test applied until equilibrium is reached. For this test, three different pressures were used.

A common history was obtained for all samples by using the same procedure of preparation and each result was obtained with a new sample which had not already been used for the determination of another point of the compaction curve.

\section{RESULTS AND DISCUSSION}

\section{Compaction of binary mixtures of fine sand and clay}

Except in the case of pure compacted montmorillonite clay, all the curves show a maximum in density (Figs. 1, 2, 3) which has been known for a long time (Maddison, 1944; Zeigler, 1948; Seed and Chan, 1959; Terzaghi and Peck, 1961; Gordon et al., 1964; Alberro, 1967; Clegg and Paul, 1967).

Turnbull and Foster (1957) showed that at lower water contents the material's dry bulk density either decreases or remains more or less constant, but no conclusion has been drawn from this observation. Faure (1978) has studied the shapes of these compaction curves at low water contents in greater detail. The materials compacted in the present study show even more clearly the same type of behaviour, which is linked both to the physical characteristics of the material and to the mechanical characteristics of the test.

In the case of compaction to the same energy $\left(E_{0}\right)$ of two sand-kaolinite mixtures (Fig. 1), it appears that the higher the clay content of the material the lower the maximum densities obtained and the higher the water contents at which they are obtained. This is a well known phenomenon in the determination of maximum density (Giulani and Robledo, 1963; Clerin, 1973) but here, at low water contents, a trend line can be noted which ends at a characteristic water content $w^{\mathrm{c}}$ (Faure, 1974). This water content appears to be proportional to the clay content of the mixtures.

In the case of compaction of the same material, relatively rich in kaolinite 
(FK 31, Fig. 1) at increasing levels of compactive energy, the mixture is more compacted and the characteristic water content $w^{\mathrm{c}}$ is lowered. This phenomenon too has been known for a long time to hold for the maximum bulk density (Lambe, 1958; Johnson and Sallberg, 1962).

It appears (Fig. 2) that with sand-montmorillonite mixtures the behaviour is similar but the characteristic water content $w^{\mathrm{c}}$ is harder to locate. When

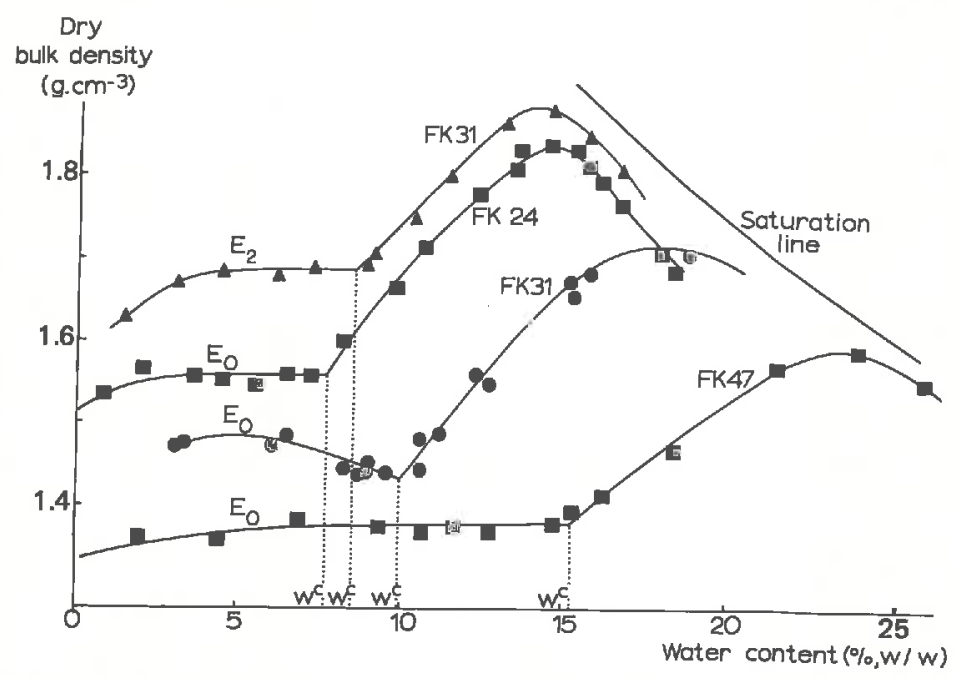

Fig. 1. Influence of clay content in fine sand-kaolinite clay mixtures (FK), with different contents of kaolinite $(24,31$ and $47 \%$ ) and two levels of energy of compaction, on critical water content $w^{\mathrm{c}}\left(E_{0}=0.6 \mathrm{MJ} \cdot \mathrm{m}^{-3} ; E_{2}=2.4 \mathrm{MJ} \cdot \mathrm{m}^{-3}\right)$.

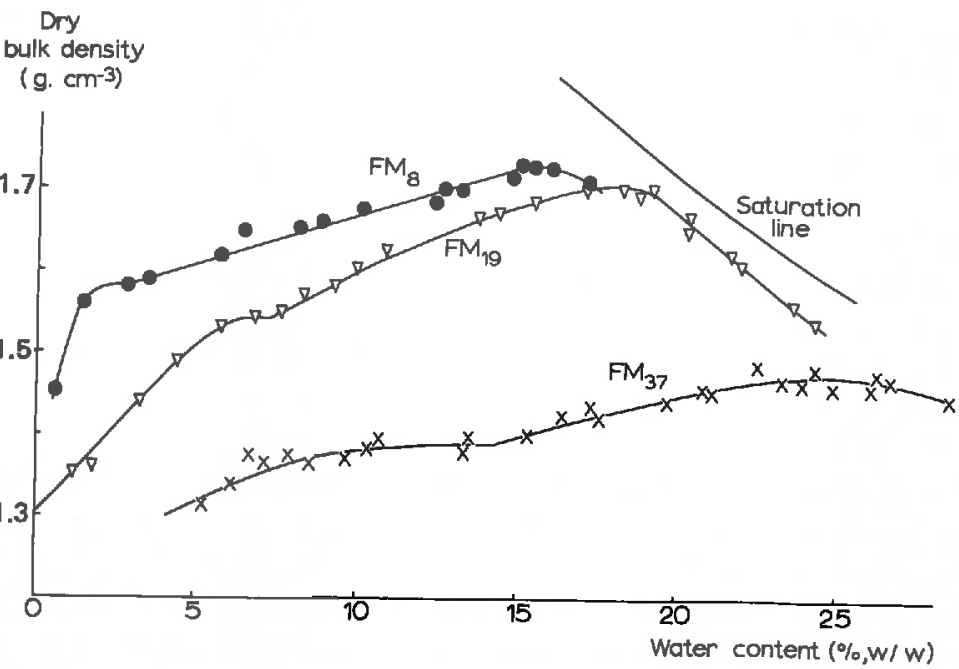

Fig. 2. Compaction curves of fine sand-montmorillonite clay mixtures (FM), with different contents of montmorillonite $(8,19$ and $37 \%)$, at energy of compaction level $E_{0}=0.6$
$\mathrm{MJ} \cdot \mathrm{m}^{-3}$. 


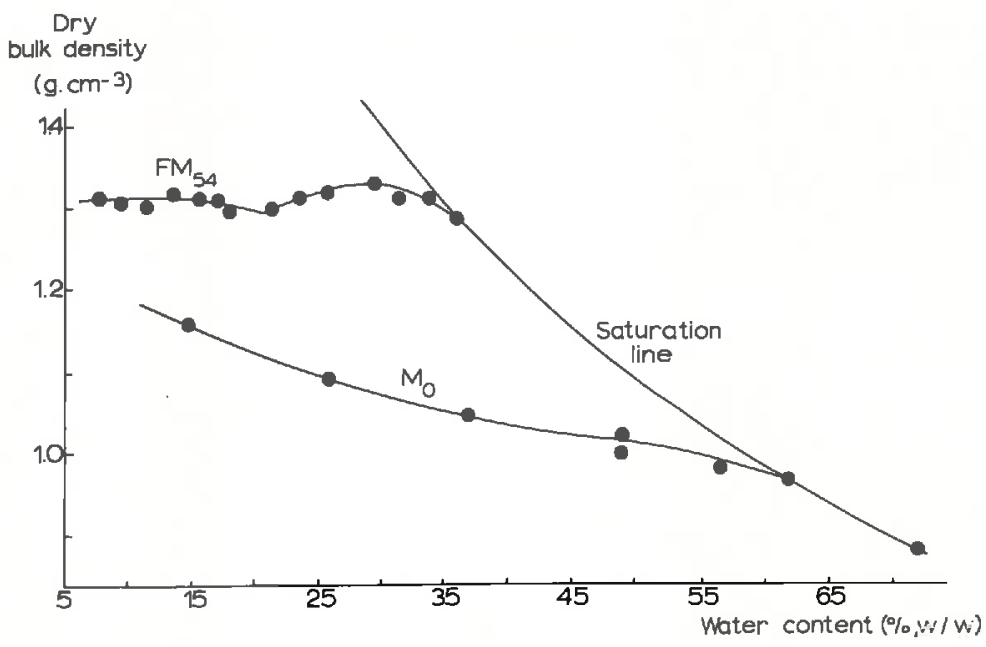

Fig. 3. Compaction curves of a fine sand-montmorillonite clay mixture with a high clay content $(54 \%)$ and of a pure montmorillonite clay $\left(\mathrm{M}_{0}\right)\left(E_{0}=0.6 \mathrm{MJ} \cdot \mathrm{m}^{-3}\right)$.

the montmorillonite clay content increases, the characteristic point becomes less noticeable and disappears completely for pure clay (Fig. 3). This characteristic point is also easily visible on similar graphs of most natural soils, which means the existence of this point appears not to be a phenomenon due to the condition of the particular preparation of a material, but a general one.

The water content $w^{\mathrm{c}}$ of this characteristic point is such that generally at lower water contents the material reaches compactness almost independently of the water content, while at higher water contents the compacted dry bulk density increases markedly with increasing water content. As a consequence this point has been called the Compaction Sensitivity Threshold (CST).

Fig. 4 shows that the value of the water conterit $w^{c}$ of the mixture increases as a linear function of the clay content. The correlation between the two parameters is very good, but in the relationship $w^{\mathrm{c}}=w^{\mathrm{a}} \cdot$ clay content, the magnitude of the proportionality coefficient $w^{\text {a }}$ depends on the kind of clay in the mixtures and on the energy used for compaction. For kaolinite it equals 0.32 for $E_{0}=0.6 \mathrm{MJ} \cdot \mathrm{m}^{3}, 0.27$ for $E_{2}=2.4 \mathrm{MJ} \cdot \mathrm{m}^{-3}$ and 0.37 for $E_{1}=0.15 \mathrm{MJ} \cdot \mathrm{m}^{-3}$. For montmorillonite clay it equals 0.38 at $E_{0}=0.6 \mathrm{MJ} \cdot \mathrm{m}^{-3}$. It may be assumed that at the CST the water in the mixture is totally absorbed by the clay and is not present in the pore space. Therefore, a material becomes sensitive to compaction only when the clay it contains has reached a particular hydration stage, independent of the particle size distribution (Faure, 1978; Guerif and Faure, 1979) but dependent only on the nature of the clay and on the intensity of the energy of compaction. 


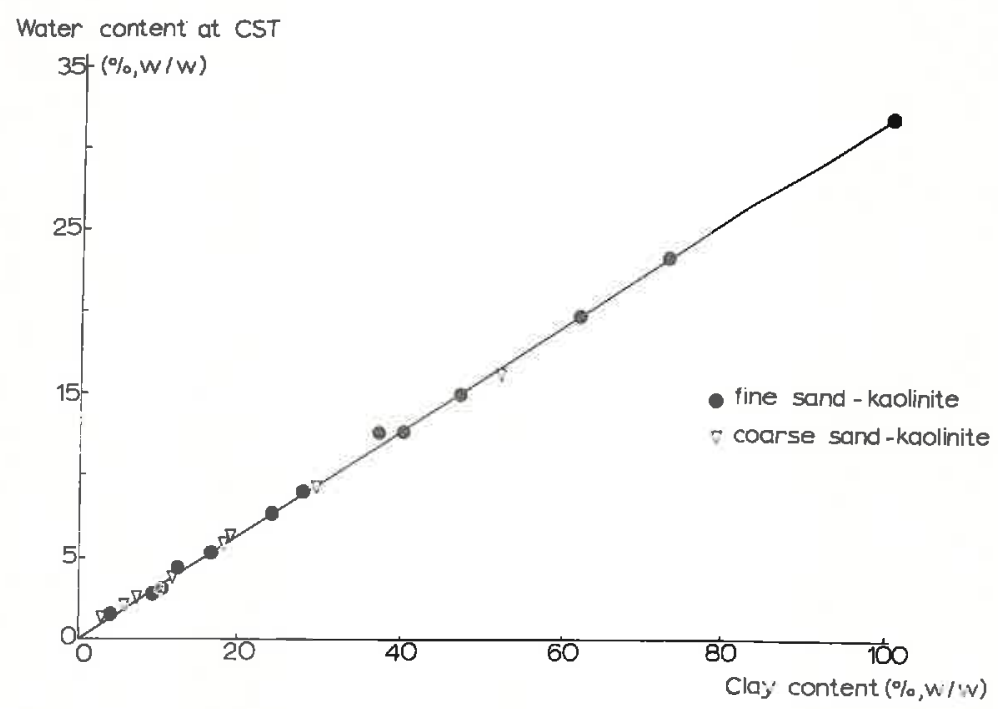

Fig. 4. Water content at the compaction sensitivity threshold (CST) versus clay content of sand-kaolinite mixtures $\left(E_{0}=0.6 \mathrm{MJ} \cdot \mathrm{m}^{-3}\right)$.

\section{Mechanical characteristics of clay at the compaction sensitivity threshold (CST)}

\section{Plastic limit}

A large number of quick undrained triaxial tests $\left(1 \mathrm{~mm} \cdot \mathrm{min}^{-1}\right.$ speed of compression and respectively, $0,0.1,0.2,0.3$ and $0.4 \mathrm{MPa}$ ambient pressure), at different water contents, both on the pure kaolinite $\mathrm{K}_{0}$ and on the mixture FK 31, compacted according to the same procedure as described before, gave further insight (Faure, 1974, 1978).

It appears from Fig. 5 that when the water content increases the angle of internal friction at first remains nearly constant or decreases slowly, but then decreases rapidly in both cases. The point corresponding to this discontinuity is the water content $\left(w^{\mathrm{c}}\right)$ at CST. It therefore appears that above this water content, because the friction angle decreases quickly, the clay allows an easier shifting of the sand grains with less and less resistance when the water content increases. In other words, the clay becomes a lubricant at water contents above this threshold value (Faure, 1971).

However, in determining Atterberg's plastic limit, the material worked upon at a small energy undergoes a longitudinal elongation, and the sample breaks when the friction angle is high enough with respect to the energy applied. Therefore, the phenomena which appear at the breaking point and at CST have the same causes for different levels of energy applied and for different ways of application. This CST can be considered as the plastic limit of the clay with respect to the energy of the test. Thus, provided the level of the energy applied is well defined, Atterberg's definition becomes a 


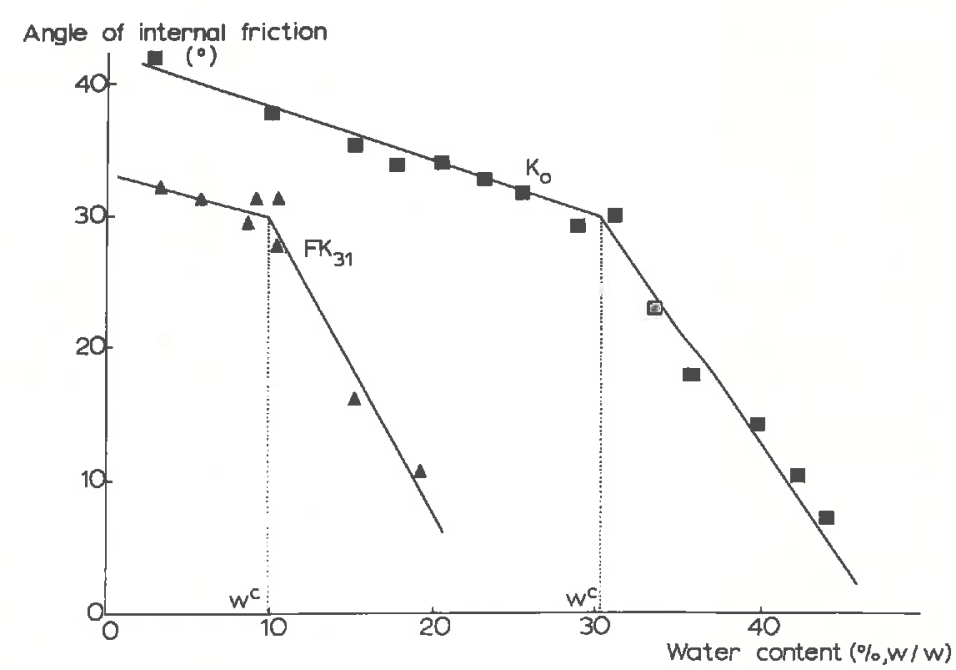

Fig. 5. Angle of internal friction versus water content of a pure kaolinite clay $\left(\mathrm{K}_{0}\right)$ and of a fine sand-kaolinite clay mixture $(31 \%$ kaolinite $)\left(E_{0}=0.6 \mathrm{MJ} \cdot \mathrm{m}^{-3}\right)$.

generalizable notion, which offers the advantage of removing the arbitrary aspect of his test when linked to fundamental concepts, such as the void ratio of clay and the energy applied. Consequently, it may be concluded that the two notions of plastic behaviour in rupture and in plasticity, as shown by Atterberg, are identical.

\section{Liquid limit}

It will be shown that it is also possible to extend the notion of the liquid limit and to place it in the context of the compaction curve.

The evaluation of the compactive energy in the liquid limit test is relatively easy because, similarly to the Proctor test, it involves an impact energy. It can be estimated that the energy developed is in the order of $2 \mathrm{~kJ} \cdot \mathrm{m}^{-3}$, which is about 300 times smaller than the energy used in the Proctor test.

Seed et al. (1964) considered that, at the liquid limit, the soil is saturated, except when there is little clay. Taking into account experimental error, this has been verified in the case of two pure clays $M_{0}$ and $K_{0}$, bringing an additional accuracy: this limit is the water content under which the material is not saturated and above which the saturation is complete for a given level of compactive energy. However, even at very high water contents, compaction by the Proctor method never gives total saturation. It is well known that above the maximum bulk density obtained by the Proctor test, the bulk densities become asymptotic to the $100 \%$ saturation line, and the results shown in Figs. 1 to 3 are no exception.

From the present study it appears that these results are due to the method itself: when measuring the compactness of clay $\mathrm{K}_{0}$ at different water contents after drained oedometry, results are obtained which are in accor- 
dance with expectations, and similar to those of nker (1969). From Fig. 6 it appears that the compression curve is no longer asymptotic to the saturation line and the intersection of the two curves defines the maximum compaction. Indeed, at higher water contents this type of test causes consolidation of the material, and once equilibrium is obtained the material has the maximum water content $\left(w^{1}\right)$ and the maximum dry density.

In addition, it was found that samples with water contents lower than $w^{1}$, when placed in the oedometer do not lose any water during the applica-

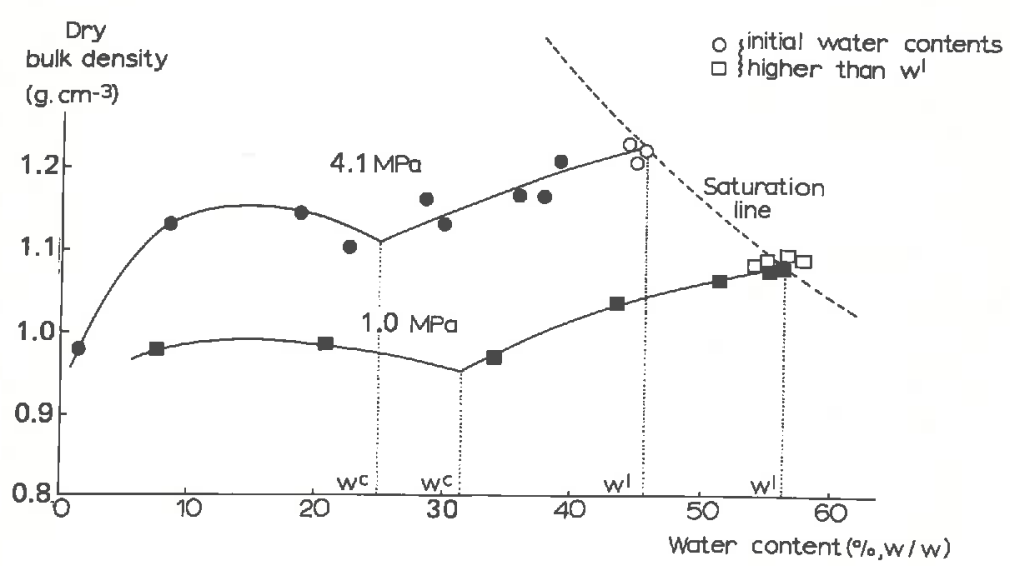

Fig. 6. Static drained compression curves of kaolinite clay at two levels of compactive energy.

tion of the load. If, once equilibrium is obtained, the samples are still loaded but are wetted by capillarity alone, the new equilibrium gives saturated samples at the same maximum dry bulk density and water content $w^{1}$ as before. This limit $\left(w^{1}\right)$ therefore represents the state of the equilibrium saturation of the material submitted to a given pressure.

From these results, it may be concluded that there exists, for a given level of energy, a liquid limit in the fundamental meaning of the word. Above this water content, the material is essentially noncompressible and any change in volume is then due to consolidation, i.e. to a loss of water. In either the Proctor test or in an undrained oedometer test, the compaction curve cannot reach the saturation line because of entrapped air, and any increase in the water content of the sample inevitably causes a decrease of its density. The compaction curves therefore show that the liquid and plastic limits are related to a particular level of energy.

The location of the plastic limit is dependent on the intensity of the energy applied on the mode of application (Fig. 7), but the liquid limit, by definition, is situated on the saturation line and its position depends only on the intensity of the energy applied. Thus, the plasticity index compares two parameters which have become really comparable as they have been obtained under similar energetic conditions. This result would certainly modify rela- 


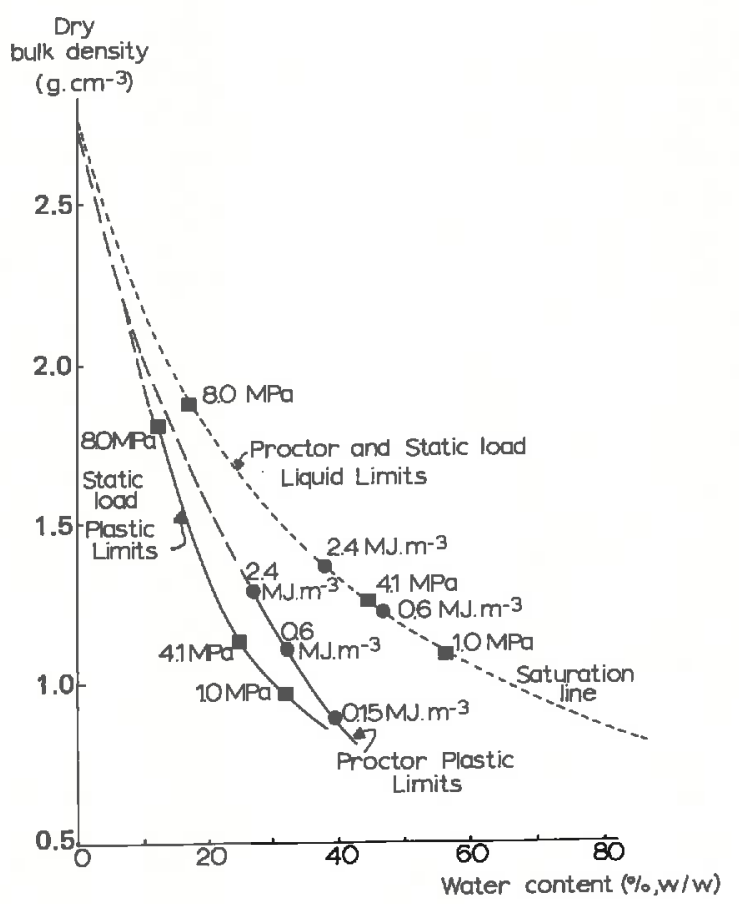

Fig. 7. Kaolinite plastic and liquid limit variations related to different levels and modes of application of compactive energy.

tionships between plasticity index and other parameters as established by Seed et al. (1964), Dumbleton and West (1966), and by Voight (1973). It is important to notice (Fig. 7) that the plasticity index decreases with increasing intensity of the energy applied.

\section{CONCLUSION}

The analysis of the compaction curves of binary sand-clay mixtures shows a particular water content called compaction sensitivity threshold. This water content is proportional to the clay content of the sample, and depends on the mineralogical nature of the clay. This compaction sensitivity threshold appears to be the plastic limit of the material under well-defined energetic conditions of compaction.

The fact that the maximum density is near the saturation line when a sample is compacted under impact energy is due to the method itself. The drained oedometer tests showed that this maximum must be on the saturation line and so it appears to be the liquid limit of the material under the same energetic conditions as the plastic limit defined before. Thus the corresponding plastic index compares two characteristic water contents under identical experimental conditions. 
It is well known that Atterberg's limits have been established by using either a low level of compactive energy (liquidity) or by badly defined tests (plasticity). However, the present results give a more fundamental basis to the plastic and liquid limits, generalizing Atterberg's definition, provided the level of energy applied is well defined.

\section{REFERENCES}

Alberro, J., 1967. Estudio de une correlation entre pruebas de compactation estatica y dinamica. 3rd Panamerican Conf. Soil Mech. Found. Eng., Venezuela, III. 9: 143-156.

Burmister, D.M., 1964, Environmental factors in soil compaction. Compaction of Soil. Symp. 67th Annual Meeting. Chicago, IL, ASTM Special Bull., 377: 47-66.

Clegg, B. and Paul, M.J., 1967. The effect of compaction methods on the pore pressure in laboratory test specimens. 5th Australia-New Zealand Conf. Soil Mech. Found. Eng.,
pp. 49-54.

Clerin, J., 1973. Compactage sur chemin oedométrique, avec et sans vibrations, de milieux pulvérulents. Remarques sur les essais in situ. Thesis, Grenoble, France, $209 \mathrm{pp}$.

Dumbleton, M.J. and West, G., 1966. Some factors affecting the relation between clay minerals in soils and their plasticity. Clay Miner., 6: 179-193.

Faure, A., 1971. Contribution à l'étude du mécanisme du compactage des sols. Notion de potentiel du librufication. Ann. Agron., 22: 487-513.

Faure, A., 1974. Des caractéristiques mécaniques de la fraction argileuse dans le mécanisme de tassements des sols. C.R. Acad. Sci., Série D, 278: 1175-1178.

Faure, A., 1978. Comportement des sols au compactage: Rôle de l'argile et conséquences sur l'arrangement des grains. Thesis, Grenoble, France, 179 pp.

Giulani, F. and Robledo, S., 1963. Nuevo metodo de analysis de compactation de suelos. 2nd Panamerican Conf. Soil Mech. Found. Eng., Brazil, Vol. II: 397-416.

Gordon, B.B., Hammond, W.D. and Miller, R.K., 1964. Effect of rock content on compaction characteristics of clayey gravel. Compaction of Soil. Symp. 67th Annual Meeting, Chicago, IL, ASTM Special Bull., 377: 31-46.

Guerif, J. and Faure, A., 1979. Rôle de la matiêre organique sur le comportement des sols au compactage. I. Etude statistique. Ann. Agron., 30: 387-399. Ilker, U., 1969 . Ecrouissage et fragilité comparée de plusieurs argiles. Thesis, Grenoble,
France, $130 \mathrm{pp}$.

Johnson, A.W. and Sallberg, J.R., 1962. Factors influencing compaction test results. Highway Res. Board Bull., 319, 148 pp.

Lambe, T.W., 1958. The structure of compacted clay. J. Soil Mech. Found. Div. Proc. Am. Soc. Civil Eng., (SM 2) 1654: 1-34.

Maddison, L., 1944. Laboratory tests on the effect of stone content on the compaction of

s soil mortar. Roads Road Constr., 1: 37-40.

McRae, J.L. and Rutledge, P.C., 1952. Laboratory kneading of soil to simulate field compaction. Highway Res. Board Proc., 31: 593-600.

Seed, H.B. and Chan, C.K., 1959. Structure and strength characteristics of compacted clays. Proc. Am. Soc. Civil Eng., (SM 5): 85-128.

Seed, H.B., Woodward, R.J. and Lundgren, R., 1964. Fundamental aspects of the Atterberg limits. J. Soil Mech. Found. Div. Proc. Am. Soc. Civil Eng., (SM 6): 75-105. Terzaghi, K. and Peck, R.B., 1961. Mécanique des Sols Appliquée. Dunod Edn., Paris,
565 pp.

Turnbull, W.J. and Foster, C.R., 1957. Compaction of a graded crushed stone base course. Proc. 4th Intern. Conf. Soil Mech. Found. Eng., 2: 181-185.

Voight, B., 1973. Correlation between Atterberg plasticity limits and residual shear strength of natural soils. Géotechnique, 23: 265-267.

Zeigler, E.J., 1948. Effect of material retained on the No. 4 sieve on the compaction test of soils. Highway Res. Board Proc., 28: 409-414. 